of the company as an association of members, the modern doctrinal basis of the allocation of powers rests on a quite different conceptualisation of the company as a reified institution. In the absence of a fundamental reform, therefore, the law cannot hope to reconcile these conflicting rules in a principled way.

Ross GRANTHAM

\title{
STATUTORY TRUSTS AND INSOLVENCY
}

IT is well settled that a statutory trust over a company's property is brought into existence when the court makes a winding-up order (see Ayerst (Inspector of Taxes) v. C\& K Construction Ltd. [1976] A.C. 167). However, the relationship between the debt owed by the company to a creditor and that creditor's interest under the statutory trust has rarely been considered in any depth. Wight v. Eckhardt Marine GmbH [2003] UKPC 37, [2003] 3 W.L.R. 414 provides important guidance in this regard.

Wight v. Eckhardt Marine $G m b H$ concerned a claim by Eckhardt against the Bank of Credit and Commerce International (Overseas) Ltd. ("BCCI $(\mathrm{O})$ ") under a guarantee, governed by the law of Bangladesh, issued by a branch office of $\operatorname{BCCI}(\mathrm{O})$ in Bangladesh shortly before the collapse of the BCCI group in July 1991. As BCCI(O) was incorporated in the Cayman Islands, a winding-up petition was presented there in July 1991 and, in January 1992, a winding-up order was made. In due course, the appellants were appointed as liquidators of BCCI(O). In May 1992, Eckhardt entered a proof of debt in the winding up. The liquidators initially indicated that they would accept Eckhardt's proof. However, in August 1992, the Bangladeshi Government put in place a scheme for the reconstruction of the branch of $\mathrm{BCCI}(\mathrm{O})$ in Bangladesh. The scheme created a new entity, called the "Eastern Bank", which took over all the assets of BCCI(O)'s branch in Bangladesh. The scheme also discharged the liabilities of $\mathrm{BCCI}(\mathrm{O})$ in Bangladesh and created corresponding obligations on the part of the Eastern Bank. In December 1995, the liquidators rejected Eckhardt's proof of debt because of the apparent discharge of BCCI(O)'s liability according to Bangladeshi law. Eckhardt protested, arguing that when the court made its winding-up order (in January 1992) the original debt owed by BCCI(O) was replaced by an interest under a statutory trust; and, as a consequence, thereafter the law of Bangladesh became irrelevant, since it was not the governing law of the trust. 
Lord Hoffmann, delivering the opinion of the Privy Council (Lords Hoffmann, Nolan, Hobhouse of Woodborough, Scott of Foscote and Walker of Gestingthorpe) rejected Eckhardt's contention. Whilst not doubting that the company became a trustee of its assets for its creditors upon the making of the winding-up order, Lord Hoffmann observed (para. [22]): “... their Lordships do not understand how this can affect the question of who counts as a creditor entitled to prove and receive a distribution under the statutory trusts". In particular, although the making of a windingup order restricted creditors to a collective enforcement procedure, it did not (para. [27]) "create new substantive rights in the creditors or destroy the old ones". As Lord Hoffmann explained (para. [35]): "... the right to participate at any stage in the process of collective enforcement by liquidation depends upon being a creditor. So that when the debt was discharged under its proper law, it ceased to be provable in the Cayman Islands liquidation and was properly rejected".

The question whether a winding-up order creates "new substantive rights" and destroys "the old ones" (above) was considered in Re Cases of Taffs Well Ltd. [1992] Ch. 179, where Judge Paul Baker Q.C. (sitting as a judge of the High Court) spoke specifically of the acquisition of "new rights" (at 194), commenting (at 191): "One may conclude that the effect of an order to wind up is to convert the contractual rights of the creditors into proprietary rights under a trust". Although Re Cases of Taffs Well Ltd. was not cited before the Privy Council, there can be no doubt that such comments, to the extent that they suggest that new substantive rights are created, can no longer be regarded as good law.

The facts in Wight v. Eckhardt Marine $G m b H$, in particular the combination of a local liquidation and the foreign restructuring of a branch office, were unusual; nevertheless the general principle of English law to be extracted from Lord Hoffmann's judgment is that a liquidator should not make a distribution to a person who, under an applicable foreign law, has ceased to be a creditor by the time the distribution is due to be made. A further question is whether this principle may apply in a situation other than a discharge under the applicable foreign law. For example, a company may go into liquidation in England with certain debts governed by Japanese law and, under Japanese law, there may be a limitation period that expires a few months after the English court makes its winding-up order. In this scenario it might be argued that, pursuant to the Foreign Limitation Periods Act 1984, the English court must apply the Japanese limitation period and therefore, by the time the English liquidator is in a position to make any distribution, the 
Japanese "creditors" will have ceased to hold enforceable debts. The answer appears to lie in section 1(3) of the 1984 Act. Section 1(1) of the 1984 Act requires the English court to give effect to a foreign limitation period (where part of the applicable lex causae) in relation to "any action or proceeding in a court in England". Further, section 1(3) states that English law determines "whether, and at what time, proceedings have been commenced" (emphasis added). The presentation of a winding-up petition in England is regarded as the commencement of an action for limitation purposes (Re Karnos Property Co. Ltd. [1989] B.C.L.C. 340). Hence time will cease to run when a winding-up petition is presented. (In relation to non-petitioning creditors, see further Re Cases of Taffs Well Ltd., above.) Thus, in this commentator's opinion, the expiration of a foreign limitation period after the making of a winding-up order in England can safely be ignored by an English liquidator.

In conclusion, the significance of Wight v. Eckhardt Marine $\mathrm{GmbH}$ is twofold: the judgment provides an explanation of the relationship between a creditor's debt and the statutory trust arising upon liquidation; and their Lordships have also stressed that the right to participate in a distribution depends upon the retention of the status of a creditor up to the time the liquidator makes the distribution. The judgment does, however, leave some doubt as to the circumstances in which such status may be lost.

P.St.J. SMART

\section{CHANGE OF POSITION IN INSOLVENCY}

Rose v. AIB Group [2003] EWHC 1737, [2003] 1 W.L.R. 2791 involved an application by the liquidator of a construction company, Tain, for a declaration of the invalidity of certain payments under section 127 of the Insolvency Act 1986. The section renders void, subject to validation, all dispositions of company property after the commencement of the winding up, which is deemed to be when the petition was presented (Insolvency Act 1986, section 129). Customs and Excise presented a winding up petition on 4 February 1997. Payments in and out of the company's accounts continued, however, until 5 September 1997, when AIB ("the bank") became aware of the advertisement of the petition. By that time the debts of $£ 49,504$ had been fully paid off. The sole director of Tain, Mr. Bernard, had given a personal guarantee of Tain's overdraft, secured by a charge over his home. The bank released that charge in January 1999. In 2001 the liquidator queried 